\title{
Employee engagement: Leveraging strengths and underpinning weaknesses (identifying the factors underlying employee engagement levels in an organization)
}

\author{
Sona Saran \\ American Express India Private Ltd., Haryana, India \\ Email address: \\ saransona@yahoo.com
}

\section{To cite this article:}

Sona Saran. Employee Engagement: Leveraging Strengths and Underpinning Weaknesses (Identifying the Factors Underlying Employee Engagement Levels in an Organization). Journal of Human Resource Management. Vol. 2, No. 3, 2014, pp. 47-51.

doi: $10.11648 /$ j.jhrm.20140203.11

\begin{abstract}
Employee Engagement has become one of the burning issues for the Human Resources function of any organization, small or large, public or private, new or long established. Attrition rates have shot up largely and engagement levels have gone down. There are a number of factors which are not even directly related to work that determine the levels of satisfaction and engagement like health, flexibility, alignment of interests and goals. The areas that will bring maximum change in engagement scores and levels need to be identified. Through this paper, I intend to explain one such framework for identification and prioritization of these actionable areas and items - The AI Matrix or Awareness - Implementation Matrix based on a research done by me on a large multinational bank. At the end, there are some of the initiatives that can help increase the awareness levels.
\end{abstract}

Keywords: Employee Engagement, Human Resource, Awareness, Job Satisfaction, Work Life Balance

\section{Introduction}

Human Resource professionals have been constantly juggling with it in an effort to be able to touch higher engagement scores, reduce employee turnover rate and producing satisfied and committed employees. Dissatisfied employees leaving the organization are a threat to confidentiality of information by a person who is leaving the organization. Researches have shown that engaged employees are five times less likely to have safety-related incidents than disengaged ones. [11]

The engagement of an employee with the organization depends on a number of factors which might be very indirectly related to their work. These include increased employee satisfaction levels in terms of responsibilities allocated being in line with interests and capabilities, work life balance, compensation, health, career counseling, financial aid, appreciation and acknowledgement of work, healthy criticism, and flexibility in working methodologies still maintaining the standard of the existing processes. (Gemma Robertson, Smith, \& Carl Markwick, 2009). [10][5]
Sustainability of employees largely depends on these.

Engagement goes way beyond job satisfaction and motivation. It is something that the employee has to offer by going the extra mile, having a sense of belongingness towards the organization and proactively participating in organizational activities in addition to the routine work. It is not a part of their contract with the employer. (Acas Policy Discussion Papers, 2010). [1]

The idea of employee engagement varies over dimensions such as time, culture, type of organization. Different nations might have a different view of employee engagement because the practices in an organization vary with the culture. For example, in the US employees wrap their work up by the latter half of the Friday and enjoy a long weekend whereas in a country like ours people work even on the weekends. Also, since our organizations are not willing to invest heavily in this area, it is very important for them to know which is the area or initiative that will yield the best results upon investment. Most of the employees 
don't get to avail the benefits simply because they don't know about it. Financial incentives simply are not an answer to engagement. (Vance, R. J., 2006). [9]

Employees don't feel committed to their work or the organization as a whole and they tend to quit incurring the organization a loss of investment made in hiring \& training and loss of skilled and learned workforce. Researches have shown that engagement has direct relation with the revenues that the employees bring to the organization. (http://www.melcrum.com; http://www.bs-muc.de).

Engagement has been confused with job satisfaction but there is much more to it. It has been observed that some organizations fail to increase the scores further because though well implemented, their engagement initiatives are not known to their employees. So I have identified two factors that make an initiative successful - Awareness and Implementation and we have to strike a balance between them. Their scores are already in the medium range and taking the scores from medium to high is a certainly more difficult task than moving from low to medium or high as the ones with medium scores are known to be doing the usual engagement activities to reach to that medium level. The AI Matrix is more of a quantitative technique than being just a survey and qualitative analysis making it more accurate. The categorization is not based on perceptions but on the actual calculated scores.

\section{Literature Review}

Engagement can affect employees' attitudes, potential contribution to company s growth,job involvement and consequently turnover levels and various studies have demonstrated links with productivity, increasingly pointing to a high correlation with individual, group and organizational performance (Hemsley Fraser, 2008; The Conference Board, 2006).[4]

Towers Perrin (2007) [7] found that organizations with the highest percentage of engaged employees increased their operating income by 19 per cent and their earnings per share by 28 per cent year to - year.

IHRM - For the sake of maintaining good employee relations, especially in case of expatriates, the company needs to exercise a great deal of efforts in managing effectively, the process of repatriation.

An MNC, who sends out potential employee on an international assignment overseas the expatriates' indulgence in the daily state of affairs in the organizational setting abroad and the experience and expertise gained there from in all the matters relating to effective job performance will enable their home country in acquiring a competitive advantage over the other firms in the same industry and beyond. When the employee repatriates, he expects a higher position (will ask for more and better resources- Gallup Q2), or a job of higher status with increased autonomy, authority and responsibility. This, if not provided for results in disengagement. (Harter, Schmidt, Killham, Agrawal, 2006).

\section{Measuring and Quantifying Employee Engagement}

Organizations adopt different means and frameworks for measuring engagement levels and identifying the areas of improvement. For example, engagement surveys by Hewitt and Gallup Q12. These tools are based on results of hundreds of focus groups and interviews and have been highly successful. Comparisons of engagement scores reveal that those with high Q12 scores exhibit lower turnover, higher sales growth, better productivity, better customer loyalty and other manifestations of superior performance. (Thackray, J., 2001). [6] finally, complete content and organizational editing before formatting. Please take note of the following items when proofreading spelling and grammar.

\subsection{Need for Prioritizing the Actionable Items}

This is very important as devising and executing employee engagement initiatives comes out well with huge investments in terms of time, effort and money. To be able to appropriately direct this investment, organization should be able to figure out properly that which are the areas that will give maximum output given the investment. A framework to achieve this prioritization has been explained further along the content of this paper.

\subsection{Research Questions Being Addressed}

- What are the various factors which lead to disengagement (esp. Financial Institutions)

- Identifying the strengths of people and organization as a whole

\section{The Framework: Implementation - Awareness Matrix (IA Matrix)}

The success of an employee engagement initiative depends largely on two factors, Implementation and Awareness. Awareness has been used in the context that how many employees even know about the initiatives that the organizations have taken up for engaging the employees.

\subsection{IA Matrix - Framework for Employee Engagement Planning}




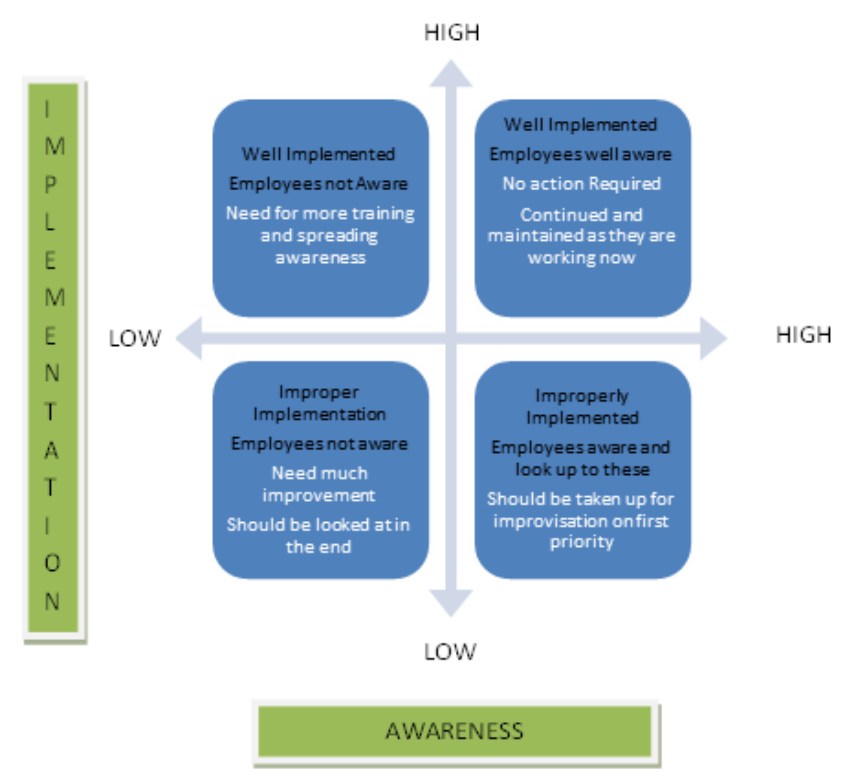

Figure 1. AI Matrix.

\subsection{How the AI Matrix Works}

Methodology for calculation of awareness levels: Identify and list down all the engagement initiatives being executed in the organization

1) Get responses on each one of them in terms of how many employees are aware of the initiatives:

Example The following question was asked to the employees

I am aware of the following engagement initiatives at $S C B$

- Wellness

- RightStart

- Block Leave

- And so on

The results were recorded as given in Figure 2

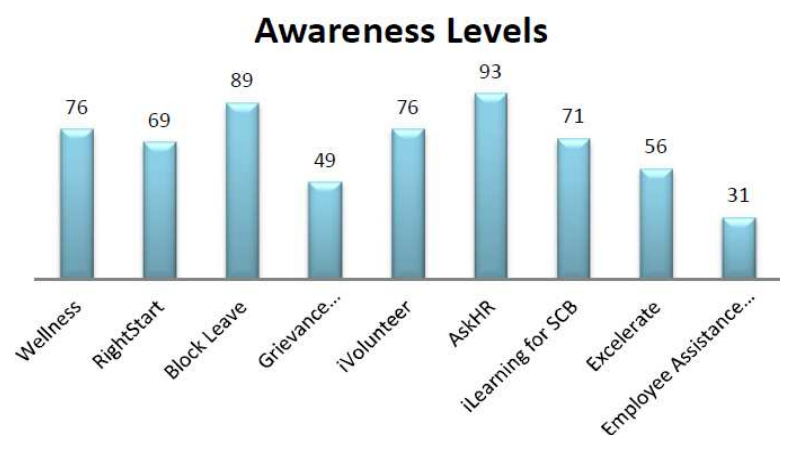

Figure 2. Awareness levels about various initiatives in terms of number of employees that know about them at SCB

2) Calculate $\%$ levels of awareness about each one of them using Eq.1

Eq. $1 \%$ Awareness $=$ Number of employees aware of $A$ / Total employees surveyed

3) Find the average value for awareness scores

4) Categorize the data as Low (Below Average) and
High(Above Average)

Methodology for Calculation of Implementation scores: Similarly for finding out the implementation scores, float a survey questionnaire on the given lines asking two questions per initiative. Sample questionnaires from the research conducted is given in $r$ to Table 1 and Table 2 given at the end of this document

1) Assign scores as follows:

$\begin{array}{ll}\text { a) Strongly Disagree } & 1 \\ \text { b) Disagree } & 2 \\ \text { c) Agree } & 3 \\ \text { d) Strongly Agree } & 4\end{array}$

2) Calculate the implementation score for each initiative by simple addition of scores on all the questions on a particular initiative.

3) Calculate an overall average implementation score by taking simple averages of implementation score of each initiative.

4) Categorize the data as Low (Below Average) and High(Above Average)

5) Organize the initiatives into the 4 quadrants of the AI Matrix based on the two scores, namely Implementation and Awareness

\subsection{Results and Interpretations}

1) Quadrant I - Well Implemented and employees are well aware. No action is required. Continue to use them as they are

2) Quadrant II - Well Implemented but lack of awareness among employees. Need for more training and spreading awareness

3) Quadrant III - Improper Implementation and lack of awareness. Much improvement needed. Should be taken up in the end.

4) Quadrant IV - Improper Implementation but employees are aware and look up to these for help. Need to be taken up for improvisation on highest priority.

\section{Spreading Awareness}

Awareness can be spread through IT, CSR, Knowledge Management etc. Information Technology has successfully collaborated and integrated with almost all the areas and functions of management including Human Resources to spread awareness. In addition, IT helps through e-recruiting, web-based trainings, compensation and talent management. IT is one of the most important factors that I identified for the organization I was working with. There are many other factors. (Blessingwhite, 2006; Vance, R. J. 2006)[2][9][10]

1. Reduce the communication Gap between junior employees and senior managers by introducing new communication channels like town halls, anonymous discussion forums

2. Goal setting and performance appraisal Feedback and involvement of the employee concerned and assigning weights to the goals 
3. Differentiation in compensation for skilled and less-skilled employees

4. Recreation Society/Events

5. Rotation of people between projects every 2-3 years

6. Brainstorming sessions - Discussion, criticism and ideation, putting them on a forum, rating them and giving rewards.

7. Health initiatives - Awareness drives, Web Based trainings

8. Flexibility of timings or locations esp. for female employees

9. Sessions on subjects that have a social stigma attached to it

10. Employee Feedback Portals

11. Lead by Example (http://www.aon.com/india)[8]

12. Counseling or financial help for employees' children's higher studies

13. Block Leave

14. Star of the month/ Best team awards

15. Official Blog for employees to jot down what they feel about organization - positives and negatives

16. Empathy Sessions

17. Knowledge Management Portal

18. 18. BUDDY PROGRAM: Identify peoples' strengths and weak areas and team them up like buddies so that both are helped and benefitted.

19. The brainstorming sessions and knowledge management initiative ensure that back-end employees' ideas are known under their own identity, they will feel more acknowledged and motivated to work.

20. Share the CSR experiences through a portal. For example, Atlantic Lottery and Novo Nordisk offer employees access to an online portal where people can upload videos of their volunteer experiences or CSR activities.

\section{Conclusion}

By examining employee engagement data, we can help the organization focus on the top drivers that will motivate employees. The companies that have a highly engaged workforce have risen to the challenge. They proactively respond to the environment, competition, and changing workforce needs. They evolve, but stay true to the values that made them successful and are well positioned for continued success. (http://www.melcrum.com)

- Engaged employees show more chances of staying with the organization for longer

- They are able to perform better and are able to utilize their potential to the fullest

- They help the organization in achieving better commercial and business performance

Having two way communication systems and building respectful yet close relationship with employees at all levels, inspiring employees by good leadership, leading by
Example always helps.

Table 1. questionnaire for employee engagement survey.

\begin{tabular}{|c|c|c|c|c|}
\hline Statement & $\begin{array}{l}\text { Strongly } \\
\text { Disagree }\end{array}$ & Agree & Disagree & $\begin{array}{l}\text { Strongly } \\
\text { Disagree }\end{array}$ \\
\hline \multicolumn{5}{|l|}{$\begin{array}{l}\text { I feel proud and happy to be a } \\
\text { part of this organization. }\end{array}$} \\
\hline \multicolumn{5}{|l|}{$\begin{array}{l}\text { My superiors handhold me } \\
\text { when required. }\end{array}$} \\
\hline \multicolumn{5}{|l|}{$\begin{array}{l}\text { My managers in the } \\
\text { organization are my role } \\
\text { models. }\end{array}$} \\
\hline \multicolumn{5}{|l|}{$\begin{array}{l}\text { I can easily communicate with } \\
\text { my superiors and peers. }\end{array}$} \\
\hline \multicolumn{5}{|l|}{$\begin{array}{l}\text { My peers are cooperative and } \\
\text { helpful }\end{array}$} \\
\hline \multicolumn{5}{|l|}{$\begin{array}{l}\text { My team members manage } \\
\text { conflicts internally. }\end{array}$} \\
\hline \multicolumn{5}{|l|}{$\begin{array}{l}\text { equal opportunities to } \\
\text { employees. }\end{array}$} \\
\hline \multicolumn{4}{|l|}{$\begin{array}{l}\text { My participation and views in } \\
\text { this organization are valued. }\end{array}$} & \\
\hline \multicolumn{5}{|l|}{$\begin{array}{l}\text { prosper in the organization on } \\
\text { my merits. }\end{array}$} \\
\hline \multicolumn{5}{|l|}{$\begin{array}{l}\text { I have access to enough tools to } \\
\text { excel in my job. }\end{array}$} \\
\hline $\begin{array}{l}\text { There are enough opportunities } \\
\text { in the organization for me to be } \\
\text { able to learn and grow. }\end{array}$ & & & & \\
\hline \multicolumn{5}{|l|}{$\begin{array}{l}\text { I am in sync with the vision and } \\
\text { mission of the organization. }\end{array}$} \\
\hline \multicolumn{5}{|l|}{ I am aware of the Employee } \\
\hline \multicolumn{5}{|l|}{$\begin{array}{l}\text { Assistance Program (EAP) to } \\
\text { release stress. }\end{array}$} \\
\hline \multicolumn{5}{|l|}{$\begin{array}{l}\text { I am aware of my job } \\
\text { responsibilities. }\end{array}$} \\
\hline \multicolumn{5}{|l|}{ I plan my day and my } \\
\hline \multicolumn{5}{|l|}{$\begin{array}{l}\text { I have flexible start and finish } \\
\text { time. }\end{array}$} \\
\hline \multicolumn{5}{|l|}{$\begin{array}{l}\text { The performance is well } \\
\text { rewarded in the organization. }\end{array}$} \\
\hline \multicolumn{5}{|l|}{$\begin{array}{l}\text { policies and practices of the } \\
\text { organization. }\end{array}$} \\
\hline $\begin{array}{l}\text { I know and live the values of } \\
\text { the Bank. }\end{array}$ & & & & \\
\hline
\end{tabular}

Table 2. questionnaire for employee engagement initiatives at $S C B$

\begin{tabular}{|c|c|c|c|c|}
\hline Statement & $\begin{array}{l}\text { Strongly } \\
\text { Disagree }\end{array}$ & Agree & Disagree & $\begin{array}{l}\text { Strongly } \\
\text { Disagree }\end{array}$ \\
\hline \multicolumn{5}{|l|}{$\begin{array}{l}\text { My work related problems are } \\
\text { solved in a timely manner }\end{array}$} \\
\hline \\
\hline \multirow{2}{*}{\multicolumn{5}{|c|}{$\begin{array}{l}\text { feasible solutions to my } \\
\text { problems }\end{array}$}} \\
\hline & & & & \\
\hline \\
\hline \multirow{2}{*}{\multicolumn{5}{|c|}{$\begin{array}{l}\text { appropriate HR related } \\
\text { information I need on AskHR }\end{array}$}} \\
\hline & & & & \\
\hline \multicolumn{5}{|l|}{ My HR related queries are } \\
\hline \multicolumn{5}{|l|}{ responded to in a timely } \\
\hline \multicolumn{5}{|l|}{ manner with appropriate } \\
\hline solutions & & & & \\
\hline I am well acquainted with the & & & & \\
\hline employee Wellness Program as & & & & \\
\hline
\end{tabular}




\begin{tabular}{|c|c|c|c|c|}
\hline Statement & $\begin{array}{l}\text { Strongly } \\
\text { Disagree }\end{array}$ & Agree & Disagree & $\begin{array}{l}\text { Strongly } \\
\text { Disagree }\end{array}$ \\
\hline $\begin{array}{l}\text { there is effective } \\
\text { communication to all staff } \\
\text { members }\end{array}$ & & & & \\
\hline $\begin{array}{l}\text { The wellness programs are } \\
\text { conducted periodically which } \\
\text { help us in enhancing } \\
\text { concentration at work }\end{array}$ & & & & \\
\hline $\begin{array}{l}\text { I am regular to work and in } \\
\text { good health because of the } \\
\text { wellness programs at the } \\
\text { workplace }\end{array}$ & & & & \\
\hline $\begin{array}{l}\text { The wellness program makes } \\
\text { me stress free and increases } \\
\text { work potential to full limit }\end{array}$ & & & & \\
\hline $\begin{array}{l}\text { I am well aware of the } \\
\text { processes and policies of the } \\
\text { organization }\end{array}$ & & & & \\
\hline $\begin{array}{l}\text { I find it easy to integrate into } \\
\text { my team and connect with the } \\
\text { members }\end{array}$ & & & & \\
\hline $\begin{array}{l}\text { I have a clear idea of my role } \\
\text { and responsibilities }\end{array}$ & & & & \\
\hline $\begin{array}{l}\text { I have acquired knowledge and } \\
\text { skills required for my work } \\
\text { over the time }\end{array}$ & & & & \\
\hline $\begin{array}{l}\text { I am able to get assistance in } \\
\text { planning my career growth } \\
\text { according to my current skill } \\
\text { set }\end{array}$ & & & & \\
\hline $\begin{array}{l}\text { The organization provides } \\
\text { counseling in work related and } \\
\text { personal issues that helps in } \\
\text { releasing stress }\end{array}$ & & & & \\
\hline $\begin{array}{l}\text { I get the right opportunities to } \\
\text { contribute to organizational } \\
\text { growth and the development of } \\
\text { communities which gives me } \\
\text { personal satisfaction }\end{array}$ & & & & \\
\hline $\begin{array}{l}\text { In the next five years, I foresee } \\
\text { myself in a regional role }\end{array}$ & & & & \\
\hline $\begin{array}{l}\text { My service to the organization } \\
\text { over the years is recognized } \\
\text { and rewarded }\end{array}$ & & & & \\
\hline $\begin{array}{l}\text { The organization provides } \\
\text { financial aid for my medical } \\
\text { expenses }\end{array}$ & & & & \\
\hline
\end{tabular}

\section{References}

[1] Acas Policy Discussion Papers. (2010). Building Employee Engagement

[2] Blessingwhite (2006). Beyond the numbers: A practical approach for individuals, managers and executives Gemma Robertson, Smith, \& Carl Markwick. (2009). Employee Engagement: A Review of Current Thinking

[3] Harter, Schmidt, Killham, Agrawal. (2006). Q12 MetaAnalysis: The relationship between engagement at work and organizational outcomes

[4] Hemsley Fraser. (2008). The HR Director, 2008; The Conference Board, 2006.

[5] Ivan T. Robertson, Cary L. Cooper. Full engagement: the integration of employee engagement and Psychological well-being

[6] Thackray, J. (2001, March 15). Feedback for real. Gallup Management Journal. Retrieved from http://gmj.gallup.com.and commitment. Alexandria, VA: SHRM Foundation.

[7] Towers Perrin. (2006, February). Winning strategies for a global workforce.

[8] Trends in Global Employee Engagement. (2011). Retrieved from http://www.aon.com/india

[9] Vance, R. J. (2006). Effective practice guidelines: Employee engagement and commitment. Alexandria, VA: SHRM Foundation.

[10] (Gemma Robertson, Smith, \& Carl Markwick, 2009).

[11] Seven Secrets to Employee Engagement By Roxanne Emmerich 